ISSN 2078-6441. Вісник Львівського університету. Серія географічна. 2013. Випуск 42. С. 106-111. Visnyk of the Lviv University. Series Geography. 2013. Issue 42. P. 106-111.

338.91

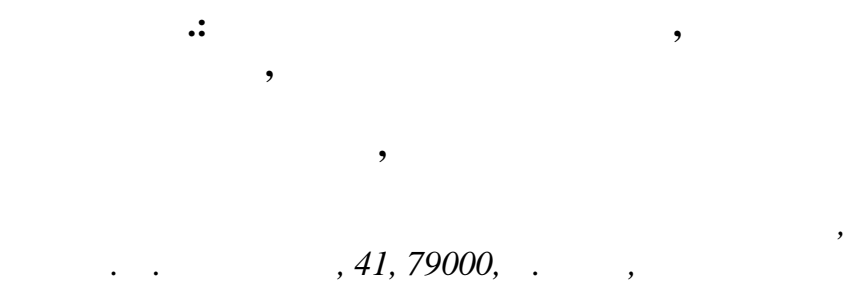

онкретизов но сутність поняття геопросторової структури поселень. озкрито роль різних геогр фічних чинників у формув нні конфігур ції т просторових форм дуже м лих міських поселень ьвівської обл. роблено типіз цію селищ міського типу т дуже м лих міст регіону 3 особливостями геопросторової структури. ро н лізов но поширення різних просторових форм дуже м лих міських поселень ьвівської обл.

лючові слов : дуже м лі міські поселення, геопросторов структур поселень, типіз ція поселень, розміщення поселень.

зовим ресурсом формув ння сукупного потенці лу кожного поселення $є$ його територія, яку х р ктеризують розміри, конфігур ція, територі льний розподіл різних функціон льних елементів, особливості з будови. зом з рівнем з безпечення житлом т інженерною інфр структурою, ці х р ктеристики території поселень суттєво вплив ють і н ступінь їхньої соці льно-економічної функціон льної спроможності.

ля позн чення геопросторової структури поселень у н уковій літер турі використовують здебільшого поняття пл нув льн форм, яке доцільно з стосовув ти н с мперед для тих поселень, територія яких формув л ся цілеспрямов но 3 певним пл ном. дн к ст новлення б г тьох дуже м лих міських поселень ьвівської обл. упродовж м йже всіх історичних періодів відбув лося стихійно, створені з певним пл ном н селені пункти з зн в ли суттєвих тр нсформ цій ун слідок великих пожеж, воєнних руйнув нь тощо, тому основні риси їхнього територі льного устрою доцільно озн чити як конфігур цію т геопросторову структуру.

дослідженні чинників формув ння т типологічних особливостей просторових форм укр їнських містечок т дуже м лих міст в жливо вр хув ти їхню спорідненість 3 іншими груп ми міст і водноч с із сільськими поселеннями. ому методологічне зн чення в ідентифік ції різних типів геопросторової структури дуже м лих міських поселень м ють як пр ці в г лузі геогр фії міст, зокрем, дослідження . ст вецького [1], . ппо [2], . ерцик [3], т к і підходи до виділення типів пл нув льних форм сільських поселень, 3 пропонов ні . усовим [4,5], . ілецьким [6] т іншими н уковцями.

сновними чинник ми, які визн чили типологічні відмінності геопросторової структури суч сних селищ т дуже м лих міст, є особливості природних умов, історико-генетичний тип поселення, н явність $б$ зових підприємств т шляхів сполучення. окрем , т кі природні елементи, як річкові долини, озер , гірські м сиви тощо, вплив ють н формув ння лінійно-видовженого х р ктеру поселень, в селищ х т

(C) ністрянськ ., ністрянський ., 2013 
міст х 3 пл ново-пр вильною конфігур цією зумовлюють комп ктно розчленов ні форми з будови, тобто н явність територі льно відокремлених ч стин поселення. одібне зн чення для м лих поселень м ють і в жливі з зн ченням шляхи сполучення. уже м лі міські поселення, які в минулому м ли ст тус міст т містечок, т кож вирізняються більш цілеспрямов но впорядков ною з будовою т н явністю історичного дміністр тивного центру. н йбільш пл ново-цілеспрямов ний х р ктер м ють ті дуже м лі міські поселення, які формув лися в новітні ч си як промислові центри чи пункти. снову їхнього територі льного розпл нув ння вже визн ч ли проектні орг ніз ції відповідно до містобудівних критеріїв.

онфігур ція т геопросторов структур безпосередньо поєднуються з типом з будови. прикл д, для комп ктних форм дуже м лих міських поселень н йбільше х р ктерн вулично-кв рт льн з будов, т кож комбінов н , менше - p ді льн . ля л нцюгових форм селищ т дуже м лих міст х р ктерні лінійно-вуличн т подекуди рядов з будов (ф с ди будинків не зорієнтов ні один н впроти одного, в одному н прямі).

ереж дуже м лих міських поселень ьвівської обл. охоплює 56 міських н селених пунктів: 34 селищ міського типу (містечк ) т 22 дуже м лі міст . якщо скл д селищ міського типу визн чений їхнім ст тусом, то виділення дуже м лих міст демогр фічними критеріями (їхня людність ст новить менше 10 тис. осіб). уже м лі міські поселення суттєво відрізняються історично-геогр фічними особливостями формув ння т фізико-геогр фічними рис ми розміщення, які з г лом і визн чили основні відмінності геопросторової структури. прикл д, 3 погляду походження і под льшого ст новлення н с мперед виділимо: 1) ті містечк і дуже м лі міст , які одерж ли міські пр в до середини VIII ст. ( елз, ібрк, уськ, т рий мбір, удов ишня, т р іль, оморяни, лесько, ирець, еликі ости, линяни, обромиль, ом рно, остиськ , еремишляни, в - уськ, дехів, удки, коле, урк , гнів, ирів, одорів); 2) містечк , що сформув лися протягом післявоєнного періоду вн слідок розвитку енергетики ( обротвір, ірник); 3) дуже м лі міські поселення, що сформув лися протягом післявоєнного періоду вн слідок прискореного соці льного розвитку сіл, викон ння ними дміністр тивних функцій ( ориня, ніздичів, убляни, ерхнє иньовидне, ові трілищ, ідбуж). кщо для першої групи х р ктерною, з звич й, є н явність історичного центру, для другої - цілеспрямов но сформов ної кв рт льно-вуличної з будови, то для третьої - поширення л нцюгових т безсистемних форм з будови, більше типових для сільської місцевості. плив ьвов як великого міст позн чився н тр нсформ ції геопросторової структури рюховичів, в но- $p$ нкового, устомитів, удного у н прямі поступового формув ння впорядков нішої кв рт льно-вуличної з будови.

жливою фізико-геогр фічною рисою всієї мережі дуже м лих міських поселень ьвівської обл. є розміщення в долині ністр, хідного угу т їхніх приток, що зумовлює лінійно-видовжені форми їхньої геопросторої структури. оширення безпосередньо в гірській місцевості х р ктерне для чотирьох селищ міського типу ( орині, ерхнього иньовидного, л вського, хідниці) т двох дуже м лих міст ( коле і урки), що помітно позн ч ється н безсистемній орг ніз ції околиць у цих поселеннях

тже, н ліз конфігур ції, пл нув льних форм т х р ктеру з будови дуже м лих міських поселеннях ьвівської обл. д в змогу виділити т кі основні типи їхньої геопросторової структури: 1) комп ктний з прямокутноподібною кв рт льно-вуличною 
з будовою; 2) комп ктний $з$ видовженою в одному н прямі кв рт льно-вуличною з будовою; 3) комп ктно розчленов ний 3 кв рт льно-вуличною з будовою; 4) комбінов ний, з поєдн нням вулично-кв рт льної, видовжено-лінійної чи р ді льнолінійної з будови; 5) комбінов ний, з поєдн нням скупченого ядр т безсистемно орг нізов них околиць; 6) л нцюговий т л нцюгово-видовжений з лінійно-вуличною т лінійно-рядовою форм ми з будови (див. рисунок). оширення більшої кількості в рі нтів геопросторової структури є х р ктерним для селищ міського типу, оскільки різном нітніші й їхні історико-генетичні особливості, дже серед них є як поселення, сформов ні з суч сними містобудівними критеріями ( ірник, обротвір), т к і порівняно нед вно тр нсформов ні сільські поселення зі спрощеним територі льним устроєм. ме тому яскр во вир жен комп ктн просторов конфігур ція з прямокутноподібною вулично-кв рт льною з будовою прит м нН двом промисловим селищ м (див. т блицю) і лише ч стково х р ктерн для м лого міст овий линів, яке

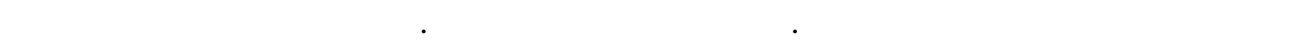
структури, як л нцюгов т л нцюгово-розг лужен з лінійно-вуличною т лінійнорядовою з будовою, т кож х р ктерні для селищ міського типу і зовсім не прит м нні дуже м лим міст м.

собливості геопросторової структури нових селищ міського типу, побудов них згідно з містобудівними критеріями ( обротвір, ірник), т міст овий линів виявляються й у їхній дуже високій густоті н селення (пон д 2200 осіб/км²) т у високій ч стці з будов них земель (пон д $60 \%$ ) і незн чній питомій в зі сільськогоспод рських угідь. роблемою под льшого розвитку цих поселень є обмежені територі льні можливості зрост ння, дже їхня з г льн земельн площ в десятки р зів менш від середніх в обл сті зн чень.

в рт льно-вуличн з будов $є \mathrm{x}$ р ктерною і для низки інших містечок т дуже м лих міст. роте в окремих вип дк х вон м $€$ видовжено-лінійну конфігур цію ( еденичі, коле, т рий мбір), зумовлену здебільшого фізико-геогр фічними чинник ми, інколи окремі ч стини поселень можуть бути відокремлені від інших як природними, т к і комунік ційними об'єкт ми, формуючи комп ктно розчленов ний тип просторової конфігур ції (селищ в но- p нкове, p сне, кло, рюховичі, удне, ідк мінь, озділ, уликів, дуже м лі міст оршин, еремишляни, устомити, в - уськ, дехів, одорів). прикл д, у селищі рюховичі окремі кв рт ли розділені смуг ми лісів, у селищі удне - лісосмуг ми т кільцевою дорогою, у селищі $\mathrm{p}$ сне - м гістр льними з лізничними й втошлях ми. ідльвівські селищ цієї групи виділяються високим ступенем з будови т густоти н селення,

в но- $p$ нкове - ще й високою ч сткою лісопокритих територій, що може бути доброю передумовою для розвитку різних виробництв деревообробної промисловості т рекре ційного господ рств .

йбільше в обл сті є комбінов них форм просторової конфігур ції т структури селищ: з поєдн нням як прямокутноподібної вулично-Кв рт льної, видовжено-лінійної чи р ді льно-лінійної з будови (десять селищ і шість дуже м лих міст), т к і скупченого ядр т безсистемно орг нізов них околиць (десять селищ і сім дуже м лих міст)

к ускл днен геопросторов структур цих дуже м лих міських поселень зумовлен в окремих вип дк х історією формув ння (більше половини з них у минулому м ли міські пр в і формув лися 3 різними містобудівними пріоритет ми), в інших особливостями гірського рельєфу й суч сного економічного профілю, що, зокрем , $\mathrm{x}$ р ктерне для туристично-рекре ційних центрів л вське і хідниця. 

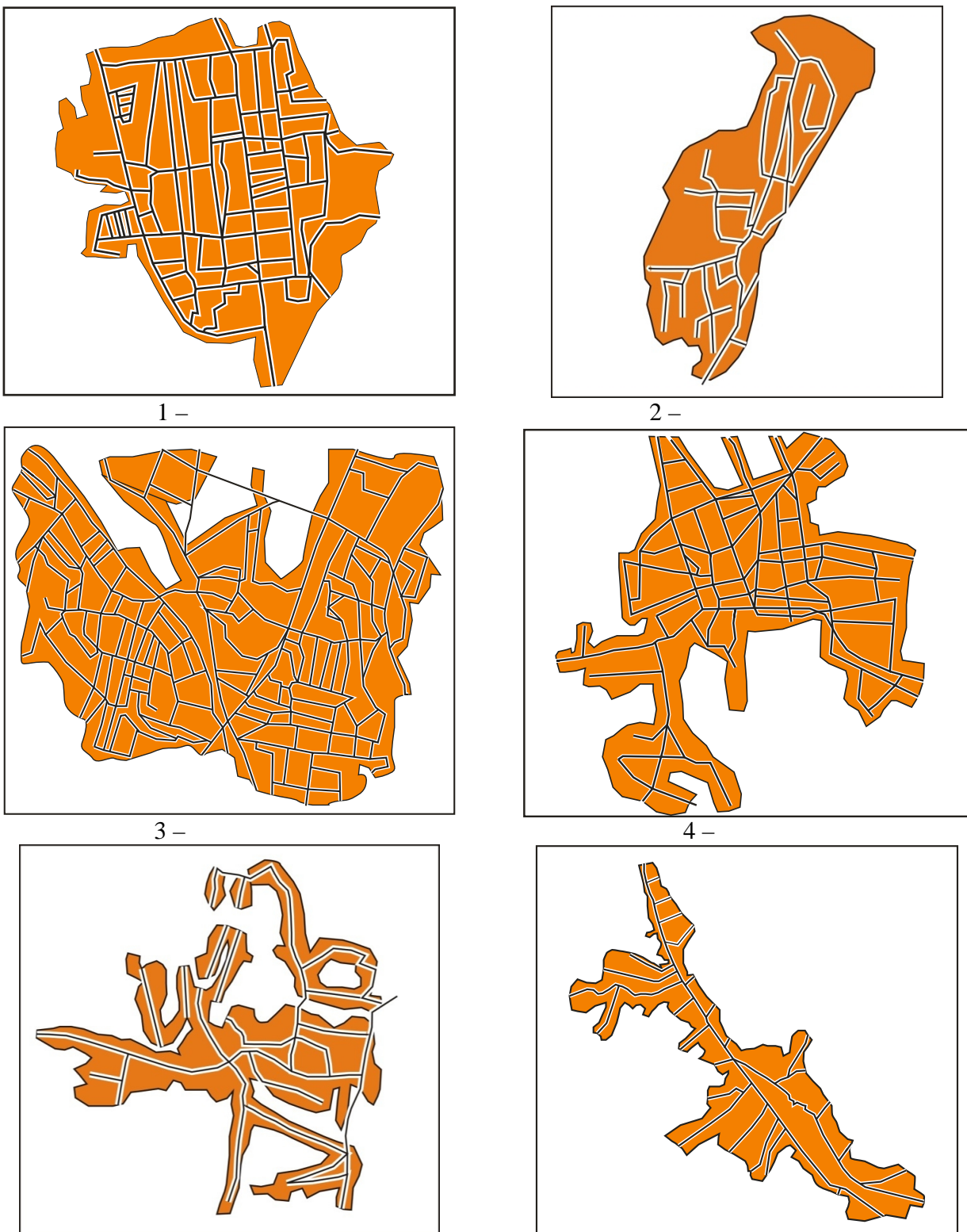

5 - линяни

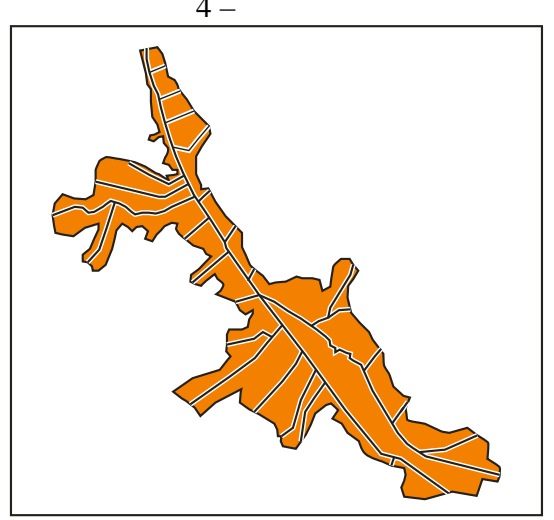

$6-$ ориня

ипи геопросторової структури дуже м лих міських поселень ьвівської обл. ифри відповід ють номер м типів з тексту.

нцюгові просторові конфігур ції з лінійно-вуличною т лінійно-рядовою форм ми з будови х р ктерні лише для селищ, які тр нсформув лися в міські поселення з сільських у другій половині ст. вн слідок викон ння ними дміністр тивних функцій чи функцій центрів лок льних систем розселення ( ориня, ш в , убляни, 
питів, ідбуж). ут м ло т кож зн чення і розміщення в гірській т передгірській смузі. ля селищ цього просторово-конфігур ційного типу х р ктерною $є$ м л ч стк з будови в структурі земельної площі (до $10 \%$ ) т зн чн питом в г земель сільськогоспод рського призн чення. явність великої ч стки сільськогоспод рських угідь у т ких поселеннях у поєдн нні 3 перев Г ми міського ст тусу т зн чним пр цересурсним потенці лом у змозі з безпечити не лише розвиток сільського господ рств , й повний цикл гропромислового виробництв . гірських селищ х цього типу н йбільшою є питом в г лісопокритих територій, що т кож може м ти різнобічне економічне зн чення.

озподіл дуже м лих міських поселень ьвівської обл.

3 просторовою конфігур цією т з будовою

\begin{tabular}{|c|c|}
\hline $\begin{array}{l}\text { ипи просторової конфігур ції } \\
\text { т } 3 \text { будови селищ }\end{array}$ & уже м лі міські поселення \\
\hline $\begin{array}{l}\text { омп ктн } 3 \text { прямокутноподібною } \\
\text { Кв рт льно-вуличною з будовою } \\
\end{array}$ & $\begin{array}{l}\text { елищ : ірник, обротвір } \\
\text { уже м лі міст : овий линів }\end{array}$ \\
\hline $\begin{array}{c}\text { омп ктн з видовженою } \\
\text { в одному н прямі кв рт льно-вуличною } \\
\text { з будовою } \\
\end{array}$ & $\begin{array}{l}\text { елищ : еденичі } \\
\text { уже м лі міст : коле, т рий мбір }\end{array}$ \\
\hline $\begin{array}{c}\text { омп ктно розчленов н } \\
\text { з кв рт льно-вуличною з будовою }\end{array}$ & $\begin{array}{l}\text { елищ : р сне, рюховичі, в но- р нкове, удне, } \\
\text { ідк мінь, озділ, кло } \\
\text { уже м лі міст : оршин, еремишляни, устоми- } \\
\text { ти, в - уськ , дехів, одорів }\end{array}$ \\
\hline $\begin{array}{c}\text { омбінов н , з поєдн нням } \\
\text { прямокутноподібної вулично- } \\
\text { кв рт льної, видовжено-лінійної чи } \\
\text { р ді льно-лінійної з будови }\end{array}$ & $\begin{array}{l}\text { елищ : еликий юбінь, ш в, ніздичів, } \\
\text { оп тин, овий ричів, ові трілищ, ирець, } \\
\text { емирів, лесько, уликів } \\
\text { уже м лі міст : уськ, елз, ібрк, еликі ости, } \\
\text { обромиль, остиськ }\end{array}$ \\
\hline $\begin{array}{c}\text { омбінов н , з поєдн нням } \\
\text { скупченого ядр т безсистемно } \\
\text { орг нізов них околиць }\end{array}$ & $\begin{array}{l}\text { елищ : ерхнє иньовидне, вирк, ур вно, } \\
\text { р ковець, герів, иж нковичі, оморяни, } \\
\text { л вське, т р іль, хідниця } \\
\text { уже м лі міст : линяни, ом рно, удки, удов } \\
\text { ишня, урк , гнів, ирів }\end{array}$ \\
\hline $\begin{array}{c}\text { нцюгов т л нцюгово-розг лужен } \\
\text { з лінійно-вуличною т лінійно-рядовою } \\
\text { з будовою }\end{array}$ & елищ : ориня, убляни, питів, ідбуж \\
\hline
\end{tabular}

більшості дуже м лих міських поселень ьвівської обл. зроблено зонув ння території з функціон льним призн ченням, що, зокрем, виявляється у виділенні земель природоохоронного, оздоровчого, рекре ційного т історико-культурного фонду. прикл д, землі природоохоронного фонду виділено у вісімн дцяти селищ х $\mathrm{H}$ площі близько 8761,6 г (76,9\% прип д $€$ н природоохоронний фонд в ноp нкового). кількох селищ х ( рюховичі, еликий юбінь, р ковець, уликів, лесько, ідк мінь, оморяни, т р іль, кло) виділено п м'ятки природи т с дово-П ркового мистецтв місцевого зн чення.

ожен $з$ типів геопросторової конфігур ції дуже м лих міських поселень м є як певні перев ги щодо своїх соці льно-економічних перспектив, т к і деякі обмеження. ому формув ння перспективних прогр м їхнього под льшого розвитку т к чи ін кше м є відбув тись з ур хув нням конкретних особливостей територі льної структури. 
1. $\mathrm{cm}$ вецький . . истем міських поселень гропромислового регіону в умов х тр нсформ ції суспільств : [моногр фія] / . . ст вецький. - ернопіль : ед.-вид. відділ $\quad$, 2005. - 160 с.

2. nnо . . еогр фия городов / . . ппо. - . : л дос, 1997. -480 с.

3. ерцик . . еогр фия городов / . . ерцик. - . . ысш. школ , 1991. - 317 с.

4. усов . оселения и постройки крестьян олт вской губернии / . усов. ., $1902 .-48 \mathrm{c}$.

5. усов . ипи сільських селищ в полудневій ч стині личини / . усов. ., $1915 .-23 \mathrm{c}$.

6. ілецький . ільське поселення т с диб в кр їнських -поч. ст. / . ілецький. - . : ук. думк , 1994. - 140 с.

m ття: н дійшл до ред кції 08.04.2013

доопр иьов н 12.07.2013

прийнят до друку 10.10.2013

\title{
GEOSPATIAL STRUCTURE OF VERY SMALL TOWNS OF LVIV REGION: FORMING FACTORS, TYPOLOGICAL DIFFERENCES, FUNCTIONAL SIGNIFICANCE
}

\author{
Natalia Dnistryanska, Myroslav Dnistryanskyy \\ Ivan Franko National University of Lviv, \\ P. Doroshenko Str., 41, UA - 79000 Lviv, Ukraine
}

The essence of the concept of geospatial patterns of settlement is concretized. The role of various factors in shaping the geographical configuration and spatial forms of very small towns of Lviv region are reveals. Typing towns and cities in the region of very small features on geospatial framework are made. The spatial distribution of the various forms of very small towns of Lviv region is analyzed.

Key words: very small urban settlements, geospatial patterns of settlement, typing settlements, location settlements.

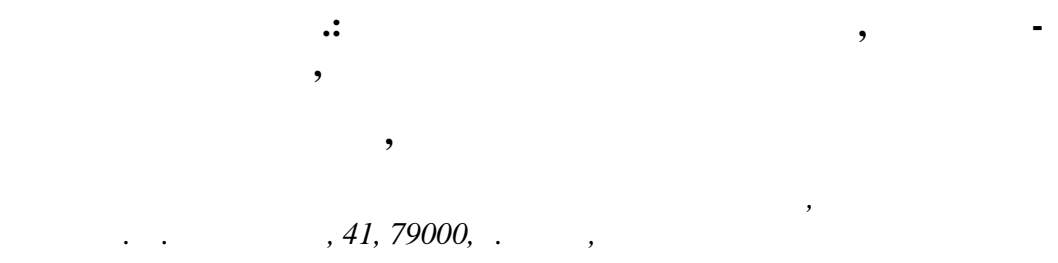

онкретизиров но сущность понятия геопростр нственной структуры поселений. скрыто роль р зличных геогр фических ф кторов в формиров нии конфигур ции и простр нственных форм очень м лых городских поселений ьвовской обл. дел но типиз цию поселков городского тип и очень м лых городов регион по особенностям геопростр нственной структуры. ро н лизиров но р спростр нение р зличных простр нственных форм очень м лых городских поселений ьвовской обл.

лючевые слов : очень м лые городские поселения, геопростр нственн я структур поселений, типиз ция поселений, $\mathrm{p}$ змещение поселений. 